\title{
Proconvulsant effects of high doses of venlafaxine in pentylenetetrazole- convulsive rats
}

\author{
J.G. Santos Junior ${ }^{1}$, \\ F.H.M. Do Monte ${ }^{2}$, \\ M. Russi2, \\ P.E. Agustine ${ }^{2}$ and \\ V.M.N.B. Lanziotti2
}

\begin{abstract}
${ }^{1}$ Laboratório de N eurofisiologia, Departamento de Psicobiologia, Escola Paulista de Medicina, Universidade Federal de São Paulo, São Paulo, SP, Brasil ${ }^{2}$ Disciplina de Farmacologia, Departamento de Morfofisiologia, Centro de Ciências Agroveterinárias, Universidade do Estado de Santa Catarina, Lages, SC, Brasil
\end{abstract}

\section{Correspondence}

J.G. Santos Junior

Laboratório de Neurofisiologia

Departamento de Psicobiologia

EPM, UNIFESP

Rua Botucatu, 862

04023-900 São Paulo, SP

Brasil

Fax: +55-11-5085-0207

E-mail: guistos@ mailcity.com

F.H.M. Do Monte received a scientific initiation grant

from CNPq (No. 109119/2000-2).

Publication supported by FAPESP.

Received September 13, 2001 Accepted February 6, 2002

\section{Abstract}

Venlafaxine, an atypical antidepressant drug, has been used to treat several neurological disorders, presenting excellent efficacy and tolerability. Clinical seizures after venlafaxine treatment have occasionally been reported when the drug was used at very high doses or in combination with other medications. The aim of the present study was to investigate the convulsant effects of venlafaxine in rats under controlled laboratory conditions. Adult male Wistar rats ( 8 per group) receiving venlafaxine or saline at the doses of $25-150 \mathrm{mg} / \mathrm{kg}$ were subjected $30 \mathrm{~min}$ later to injections of pentylenetetrazole at the dose of $60 \mathrm{mg} / \mathrm{kg}$. The animals receiving 75, 100 and $150 \mathrm{mg} / \mathrm{kg}$ venlafaxine presented increased severity of convulsion when compared to controls $(\mathrm{P}=0.02, \mathrm{P}=0.04$, and $\mathrm{P}=0.0004$, respectively). Indeed, an increased percentage of death was observed in these groups $(50,38$, and $88 \%$, respectively) when compared to the percentage of death in the controls $(0 \%)$. The group receiving $150 \mathrm{mg} / \mathrm{kg}$ showed an reduction in death latency $(999 \pm 146 \mathrm{~s})$ compared to controls (1800 $\pm 0 \mathrm{~s}$; cut-off time). Indeed, in this group, all animals developed seizures prior to pentylenetetrazole administration. Surprisingly, the groups receiving venlafaxine at the doses of 25 and $50 \mathrm{mg} / \mathrm{kg}$ showed a tendency towards an increase in the latency to the first convulsion. These findings suggest that venlafaxine at doses of 25 and $50 \mathrm{mg} / \mathrm{kg}$ has some tendency to an anticonvulsant effect in the rat, whereas doses of 75, 100 and $150 \mathrm{mg} /$ $\mathrm{kg}$ presented clear proconvulsant effects in rats submitted to the pentylenetetrazole injection. These findings are the first report in the literature concerning the role of venlafaxine in seizure genesis in the rat under controlled conditions.

Venlafaxine, an atypical antidepressant drug, has been used to treat several neurological disorders, including treatment-resistant depression (1), mild, moderate and severe depression, neuropathic pain (2), comorbid anxiety and depression (3), generalized anxiety, phobias, obsessive-compulsive
Key words

- Antidepressant

- Venlafaxine

- Convulsion

- Epilepsy

- Pentylenetetrazole

.................... disorder, panic, attention-deficit/hyperactivity (4), and others. This antidepressant medication has shown excellent efficacy and tolerability (5), besides being the only antidepressant presenting therapeutic effects when used for acute treatment (6).

Several clinical studies have reported the 
occurrence of seizures after a venlafaxine overdose, but in half of these cases, multiple drug ingestion could be identified (7-11). On the other hand, premarketing data have shown that the risk of developing seizures with therapeutic venlafaxine doses seems to be remote $(12,13)$. Thus, the aim of the present study was to determine whether venlafaxine has a proconvulsant effect in the well-known animal model of pentylenetetrazole-induced convulsion.

For this purpose we used 48 adult male Wistar rats (250-300 g) obtained from our own breeding colony, housed five to a cage with food and water available ad libitum, and maintained on a 12-h light/dark cycle (lights on at 7:00 am). Behavioral tests were conducted between 8:00 and 12:00 am. Five groups $(\mathrm{N}=8)$ received venlafaxine hydrochloride (Effexor XR ${ }^{\circledR}$, Wyeth Laboratory, São Paulo, SP, Brazil) dissolved in saline, ip, at the doses of $25,50,75,100$ and $150 \mathrm{mg} /$ $\mathrm{kg}$, respectively. The control group received saline. After $30 \mathrm{~min}$, pentylenetetrazole (Sigma, St. Louis, MO, USA) was administered at the dose of $60 \mathrm{mg} / \mathrm{kg}$, ip.

The following parameters were observed during the first 30 min: severity of convul-

Table 1. Convulsion severity, percentage of death per group, death latency and first convulsion latency in the animals treated with pentylenetetrazole and in the groups treated with pentylenetetrazole and venlafaxine at the doses of 25, 50, 75, 100 and $150 \mathrm{mg} / \mathrm{kg}$.

\begin{tabular}{llccc}
\hline Groups (N =8) & $\begin{array}{c}\text { Convulsion } \\
\text { severity }\end{array}$ & Death (\%) & $\begin{array}{c}\text { Death } \\
\text { latency (s) }\end{array}$ & $\begin{array}{c}\text { First convulsion } \\
\text { latency (s) }\end{array}$ \\
\hline Saline & $3(3-3)$ & 0 & $\mathrm{NA}^{1}$ & $55 \pm 2$ \\
Venla $(25 \mathrm{mg} / \mathrm{kg})$ & $3(3-3)$ & 12 & $1665 \pm 135$ & $66 \pm 4$ \\
Venla $(50 \mathrm{mg} / \mathrm{kg})$ & $3(3-3.5)$ & 12 & $1636 \pm 164$ & $65 \pm 5$ \\
Venla $(75 \mathrm{mg} / \mathrm{kg})$ & $4(4-4.5)^{+}$ & $50^{*}$ & $1137 \pm 256$ & $52 \pm 5$ \\
Venla $(100 \mathrm{mg} / \mathrm{kg})$ & $4(4-4.5)^{+}$ & $38^{*}$ & $1281 \pm 254$ & $52 \pm 4$ \\
Venla $(150 \mathrm{mg} / \mathrm{kg})$ & $4(4-5)^{+}$ & $88^{* *}$ & $999 \pm 146^{+}$ & $\mathrm{NA}^{2}$ \\
\end{tabular}

Latencies to death and to first convulsion are expressed as mean \pm SEM and convulsion severity as median with range in parentheses. $N A^{1}=$ not available; no animal in this group died during the cut-off time to $1800 \mathrm{~s}$. NA ${ }^{2}=$ not available; all animals in this group developed seizures prior to pentylenetetrazole administration. Venla $=$ venlafaxine.

$* \mathrm{P}<0.05$ and $* * \mathrm{P}<0.01$ (chi-square test).

$+P<0.01$ (Kruskal-Wallis test followed by the Mann-Whitney test). sion, percentage of death per group, latency of death and latency to the first convulsion. Seizure was scored as follows (14): stage 0 , no response; stage 1, ear and facial twitching; stage 2 , convulsive twitching axially through the body; stage 3, myoclonic jerks and rearing; stage 4, rolling over onto a side position, wild running and wild jumping, and stage 5, generalized clonic-tonic convulsion. Latency to death was measured up to a cut-off time of $1800 \mathrm{~s}$.

Statistical analysis for percent death per group was performed by the chi-square test. The other parameters were analyzed by the nonparametric Kruskal-Wallis test followed by the Mann-Whitney test. The level of significance was set at $\mathrm{P}<0.05$.

The group of animals that received venlafaxine at the doses of 75, 100 and 150 $\mathrm{mg} / \mathrm{kg}$ presented increased severity of convulsion $(\mathrm{U}=4.0, \mathrm{P}=0.003$; for all groups $)$ and percent death per group $\left(\chi^{2}=5.33, \mathrm{P}=\right.$ $0.02 ; \chi^{2}=3.69, \mathrm{P}=0.04 ; \chi^{2}=12.44, \mathrm{P}=$ 0.0004 , respectively) when compared to controls. Venlafaxine significantly reduced the latency to death only at the dose of $150 \mathrm{mg} /$ $\mathrm{kg}(\mathrm{U}=4.0, \mathrm{P}=0.003)$. Indeed, only at the latter dose did we observe a decrease of first convulsion latency. In this case, the animals developed seizures prior to pentylenetetrazole administration. Thus, this dose has a convulsant potential by itself. Surprisingly, although not significant, an increased convulsion latency was observed in the groups receiving venlafaxine at the doses of 25 and $50 \mathrm{mg} / \mathrm{kg}$ (see Table 1).

Venlafaxine is an antidepressant that blocks the reuptake of serotonin, noradrenaline and, to a lesser extent, dopamine. At low doses it acts only on serotonergic transmission, at moderate doses it acts on serotonergic and noradrenergic systems, whereas at high doses it affects serotonergic, noradrenergic and dopaminergic neurotransmission (15). These neurotransmitters play an important role in seizure genesis (16). Drugs that block serotonin and noradrenaline 
reuptake seem to have anticonvulsant effects (16). Thus, this effect can explain the slight increase in convulsion latency observed at the doses of 25 and $50 \mathrm{mg} / \mathrm{kg}$, but is not sufficient to account for an anticonvulsant property.

Because the proconvulsant effects of venlafaxine occurred in the rat only at high doses, the possibility is raised that they were due to a dopaminergic effect. Several studies have shown an important role of the dopaminergic system in seizure genesis. Dopaminergic receptor activation produced differential effects depending on the receptor subtype that was activated. The $\mathrm{D}_{1}$ receptor family agonist generally enhances cortical excitability and favors the emergence of epileptogenic activity. In contrast, the $\mathrm{D}_{2}$ receptor family agonist has more variable effects on cortical excitability and the expression of epileptiform discharges. Whilst it may be an oversimplification to characterize $\mathrm{D}_{1}$ and $\mathrm{D}_{2}$ receptors as mediating pro- and anticonvulsant influences in all experimental epilepsy syndromes, there is good reason to believe that stimulating $D_{1}$ and $D_{2}$ receptors is harmful and beneficial to man, respectively (17).

From a therapeutic viewpoint, $\mathrm{D}_{2}$ receptor-blocking neuroleptics have a long history of epilepsy as a side effect, and the putative antiparkinsonian $\mathrm{D}_{1}$ agonist induces fits in dopamine-depleted primates, which is predictive of its proconvulsant action in human patients (17).

Thus, we may speculate that the blockage of reuptake of dopamine by venlafaxine can exacerbate the $\mathrm{D}_{1}$ postsynaptic dopaminergic receptor effects, thereby promoting a proconvulsant effect.

However, the proconvulsant effects of venlafaxine can also be attributed to other still unknown mechanisms of action of high doses of the drug.

In humans, the minimum effective dose of venlafaxine is $75 \mathrm{mg} / \mathrm{day}(1.07 \mathrm{mg} / \mathrm{kg}$ for a $70 \mathrm{~kg}$ patient), and the maximum dose is $375 \mathrm{mg} /$ day $(5.4 \mathrm{mg} / \mathrm{kg})$. The manufacturer $\left(\right.$ Effexor $^{\circledR}$ ) recommends starting at doses of $75 \mathrm{mg} /$ day. This dose may be increased to $150 \mathrm{mg} /$ day, depending on the patient's ability to tolerate the drug and the need for a further clinical effect. Patients receiving 300$375 \mathrm{mg} /$ day showed the most treatment-related adverse effects. Therefore, the usual dose range is $75-200 \mathrm{mg} /$ day, which appears to be adequate and desirable for most patients (18). There are several views concerning the proconvulsant effects of venlafaxine, but in these studies, other drugs were administered concomitantly, or venlafaxine was administered at a very high dose. Conway and Nelson (7) reported seizure occurrence in a patient receiving long-term bupropion, lithium and venlafaxine when submitted to electroconvulsive therapy. On the other hand, Bernardo and colleagues (19) found that combined venlafaxine and electroconvulsive therapy appears to be safe when used in depressive subjects. Schlienger et al. (8) also reported seizures in a patient who received venlafaxine and trimipramine, both at therapeutic doses. In this case, these authors speculated about the pharmacodynamic and pharmacokinetic interaction between these drugs involving the CYP2D6 isoenzyme. Ripple and colleagues (9) related the death of an alcoholic subject to developed seizure activity while being treated with tramadol, venlafaxine, trazodone and quetiapine. No metabolites were found, such as acetate, acetone, lactate and pyruvate, that would be characteristically found in a person with alcohol withdrawal syndrome. Thus, the authors suggested possible iatrogenic seizures. Indeed, Zhalkovsky et al. (10) reported a case of seizures in a 22-year-old Hispanic man who took $3 \mathrm{~g}$ of venlafaxine. The patient presented tonic-clonic activity and elevation of creatinine phosphokinase (CPK) and lactate dehydrogenase (LDH). After 13 days, venlafaxine was restarted at $37.5 \mathrm{mg}$ orally twice daily. The patient tolerated the return to venlafaxine without recurrence of seizures or elevation of CPK and LDH. In 
another case (11), a patient took 26 venlafaxine tablets (50 $\mathrm{mg}$ each) and had a single episode of generalized seizure, but no further sequelae.

The present study is the first report in the literature concerning the role of venlafaxine in laboratory animal seizure genesis under controlled conditions. Redrobe and colleagues (20) demonstrated an antidepressant effect of venlafaxine in rats at doses of 8-64 $\mathrm{mg} / \mathrm{kg}$ in the forced swimming test, an animal model of depression. In the elevated plus-maze and staircase task, two animal models of anxiety, venlafaxine seems to be effective at the doses of 10-50 mg/kg (Santos
Junior JG, Do Monte FHM, Russi M and Lanziotti VMNB, unpublished results). Thus, the proconvulsant effects of venlafaxine observed in the present study were related only to high doses of the drug. In the rat, the therapeutic and proconvulsant doses of venlafaxine seem to be almost within the same range, and a number of kinetic or dynamic factors influence the increased risk of convulsion. On this basis, considering the proconvulsant effects of venlafaxine as a possible side effect in humans and laboratory animals, some caution is needed when prescribing this drug.

\section{References}

1. Schweitzer I, Burrows G, Tuckwell V, Polonowita A, Flynn P, George T, Theodoros M \& Mitchell P (2001). Sustained response to open-label venlafaxine in drug-resistant major depression. J ournal of Clinical Psychopharmacology, 21: 185-189.

2. Lynch ME (2001). Antidepressants as analgesics: a review of randomized controlled trials. J ournal of Psychiatry and Neuroscience, 26: 30-36.

3. Gorman J M \& Papp LA (2000). Efficacy of venlafaxine in mixed depression-anxiety states. Depression and Anxiety, 12 (Suppl 1): 77-80.

4. Ninan PT (1999). The functional anatomy, neurochemistry, and pharmacology of anxiety. J oumal of Clinical Psychiatry, 60 (Suppl 22): 12-17.

5. Feighner J P (1999). Overview of antidepressants currently used to treat anxiety disorders. J ournal of Clinical Psychiatry, 60 (Suppl 22): 18-22.

6. Blier P (2001). Possible neurobiological mechanisms underlying faster onset of antidepressant action. J ournal of Clinical Psychiatry, 62 (Suppl 4): 7-11.

7. Conway CR \& Nelson LA (2001). The combined use of buproprion, lithium and venlafaxine during ECT: a case of prolonged seizure activity. J ournal of Electro- convulsive Therapy, 17: 216-218.

8. Schlienger RG, Klink MH, Eggenberg C \& Drewe J (2000). Seizures associated with therapeutic doses of venlafaxine and trimipramine. Annals of Pharmacotherapy, 34: 1402-1405.

9. Ripple MG, Pestaner JP, Levine BS \& Smalek J E (2000). Lethal combination of tramadol and multiple drugs affecting serotonin. American J ournal of Forensic Medicine and Pathology, 21: 370-374.

10. Zhalkovsky B, Walker D \& Bourgeois J A (1997). Seizure activity and enzyme elevations after venlafaxine overdose. J ournal of Clinical Psychopharmacology, 17: 490491.

11. White CM, Gailey RA, Levin GM \& Smith $T$ (1997). Seizure resulting from a venlafaxine overdose. Annals of Pharmacotherapy, 31: 178-180.

12. Rudolph RL \& Derivan AT (1996). The safety and tolerability of venlafaxine hydrochloride: an analysis of the clinical trials database. J oumal of Clinical Psychopharmacology, 16 (Suppl 12): S54-S61.

13. Alldredge BK (1999). Seizure risk associated with psychotropic drugs: clinical and pharmacokinetic considerations. Neurology, 53 (Suppl 12): S68-S75.

14. Becker A, Grecksch $G$ \& Schröder $H$ (1995). N-Nitro-L-arginine methyl ester in- terferes with pentylenetetrazole-induced kindling and has no effect on changes in glutamate binding. Brain Research, 688: 230-232.

15. Bourin M (1999). Psychopharmacology profile of venlafaxine. Encephale, 25: 2125.

16. Trimble MR \& Meldrum BS (1979). Monoamines, epilepsy and schizophrenia. In: Obiols J , Ballus E, Gonzales M \& Pujol J (Editors), Biological Psychiatry Today. Elsevier, Amsterdam, The Netherlands, 470-475.

17. Starr MS (1996). The role of dopamine in epilepsy. Synapse, 22: 159-194.

18. Ellingrod VL \& Perry PJ (1994). Venlafaxine: a heterocyclic antidepressant. American J ournal of Hospital Pharmacy, 51: 3033-3046.

19. Bernardo M, Navarro V, Salva , Arrufat FJ \& Balza I (2000). Seizure activity and safety in combined treatment with venlafaxine and ECT: a pilot study. J ournal of Electroconvulsive Therapy, 16: 38-42.

20. Redrobe J P, Bouren M, Colombel MC \& Baker GB (1998). Dose-dependent noradrenergic and serotonergic properties of venlafaxine in animal models indicative of antidepressant activity. Psychopharmacology, 138: 1-8. 